\title{
Exchange rate exposure and real exports
}

\section{Mehmet Nihat Solakoglu}

To cite this article: Mehmet Nihat Solakoglu (2010) Exchange rate exposure and real exports, Applied Economics Letters, 17:5, 457-462, DOI: 10.1080/13504850801935331

To link to this article: https://doi.org/10.1080/13504850801935331

曲 Published online: 18 Feb 2008.

Submit your article to this journal

Џll Article views: 153

Citing articles: 6 View citing articles 


\title{
Exchange rate exposure and real exports
}

\author{
Mehmet Nihat Solakoglu \\ Department of Banking \& Finance, Bilkent University, Bilkent, Ankara, \\ 06800, Turkey \\ E-mail: nsolakoglu@bilkent.edu.tr
}

This study investigates the relationship between real exports and exchange rate risk for Turkish firms between 2001 and 2003. Different from earlier studies, the analysis is conducted at the firm level with an exchange rate risk specific to the individual firm. Results show that real exports are negatively impacted by an increase in exchange rate risk. In addition, size of the trade volume and the dependence on domestic market for revenue generation are found to be important for the aforementioned relationship.

\section{Introduction}

Since the breakdown of Bretton-Woods system in the 1970s, the relationship between exchange rate risk and trade flows has been investigated many times. While early theoretical work indicated that an increase in exchange rate risk would lower the volume of trade, some later studies argued that this does not have to be the case (e.g. Clark, 1973; Ethier, 1973; Hooper and Kohlhagen, 1978; Cushman, 1986; De Grauwe, 1988; Franke, 1991; Neumann, 1995). Moreover, empirical studies also did not provide evidence in favour of negative or positive association between exchange rate risk and trade flows (e.g. Hooper and Kohlhagen, 1978; Cushman, 1986; Pozo, 1992; Hassan and Tufte, 1998; Doyle, 2001; Bahmani-Oskooee, 2002; Vergil, 2002). Hence, this lack of consensus on a theoretical/empirical framework has led to a diverse and sometimes unwieldy literature. A close examination of empirical studies shows that they differ from each other significantly in the conditioning set they use. In particular, they measure exchange rate risk by a wide range of proxies ranging from SDs to conditional volatility from a GARCH-type model.
This study also investigates the relationship between exchange rate risk and trade flows. However, it differs from earlier studies in two ways. First, we focus on firm level, not on country level real exports. Second, instead of using a currency-based risk measure, we utilize a risk measure specific to individual firm. Namely, we use exchange rate exposure obtained from a market model utilizing CAPM. The main hypothesis in this study argues that exchange rate risk has a negative effect on real exports. In addition, the role of firm-specific factors on the sign and significance of this relationship is also investigated.

The remainder of this article is organized as follows. Section II discusses the model specification, data sources and results. The last section presents our main conclusions and suggestions for further research.

\section{Model Specification, Implementation and the Results}

The analysis to estimate exchange rate exposure is performed using weekly ${ }^{1}$ data at the firm level

${ }^{1}$ Weekly prices are obtained by taking weekly averages of daily prices. 
between the years 2001 and 2003. Daily stock prices, market index ${ }^{2}$ and exchange rates for USD and Euro are obtained from www.analiz.com for 136 firms in Turkey. ${ }^{3}$ All firms traded in Istanbul Stock Exchange ${ }^{4}$ with international transactions and nonmissing data are selected for the analysis. The firm level annual data is obtained from Istanbul Stock Exchange. Macro variables required for the analysis - consumer price index (CPI), gross domestic product (GDP) and unit price index for exports - are obtained from IMF's International Financial Statistics.

As suggested by Dumas (1978) and Adler and Dumas (1980, 1984), exchange rate exposure can be quantified as the sensitivity of stock returns to exchange rate movements. ${ }^{5}$ Hence, firm-specific exposure to exchange rate movements can be estimated through the following market model.

$$
R_{i, t}=\alpha+\beta_{m} R_{m, t}+\beta_{s} R_{s, t}+\varepsilon_{i, t}
$$

where $R_{i, t}$ is the firm $i$ 's return at time $t, R_{m, t}$ is the return on the market portfolio, and $R_{S, t}$ is the return on a portfolio consisting of Euro and USD. ${ }^{6}$ In this model, the exposure $\beta$ - that is, firm-specific risk - is denoted by $\beta_{s}$ and shows the sensitivity of stock returns to exchange rate movements. A $\beta_{s}$ value of one indicates that firm value moves in the same direction with the movement in exchange rates, while a $\beta_{s}$ value of zero indicates firm value is not impacted by exchange rate changes. ${ }^{7}$ Exposure $\beta_{\mathrm{s}}$ are estimated for Equation 1 for 2001, 2002 and 2003. ${ }^{8}$

Given that the ratio of import revenue to export revenue is, on average, around $82 \%$ for the firms used in this analysis, it might be important to consider the differences in the currency used for imports and exports. If firm's trade contracts are in USD for imports, but in Euro for exports, a change in the parity between USD and Euro can create an additional risk for traders. As a result, exporters do not face only with exchange rate risk but they also face with the parity risk. Equation 2 is used to estimate the following market model to take into account this additional risk.

$$
R_{i, t}=\alpha+\beta_{m} R_{m, t}+\beta_{s} R_{s, t}+\beta_{p} R_{p, t}+\varepsilon_{i, t}
$$

where $R_{p, t}$ is the percentage change in the USD/Euro parity. An increase in this ratio indicates that USD depreciates against Euro. Similar to exposure $\beta$, sensitivity of firm value to movements in the price of Euro in terms of USD, which is called parity risk, is measured with the $\beta_{p}$ coefficient.

Equation 3 is used to examine the relationship between exchange rate risk and real exports.

$$
Q_{i t}=\mu+\mathbf{X}_{i t} \beta+\varepsilon_{i t}
$$

In this equation, $Q_{i t}$ is the $\log$ of export volume of firm $i$ for year $t$. Export volume is calculated by dividing export values with the export unit price index. The vector $\mathbf{X}_{i t}$ includes a measure of economic activity in the importing country, ${ }^{9}$ a relative price measure expressed as the ratio of foreign to domestic prices, ${ }^{10}$ the bilateral exchange rates measured as the price of the USD and Euro in terms of local currency, and a measure of exchange rate risk, all in natural logarithm except the risk variable.

Three different specifications of Equation 3 are estimated with three different risk measures. Specification 1 uses absolute value of estimated exposure to proxy for firm-specific risk. ${ }^{11}$ Exchange rate risk is measured by the $\mathrm{SD}$ of the monthly bilateral exchange rate in a particular year for the second specification. ${ }^{12}$ This is a measure specific to currency and it is included in the analysis for comparison. Finally, the last specification, exchange rate exposure and parity risk, both in absolute values, are used to proxy exporters' risk. These measures are both firm-specific and while the first one takes into account the risk associated with the movements in the price of foreign currency in terms of local currency, the second measure considers the risk associated with the changes in parity between Euro and USD.

${ }^{2}$ Index includes 100 firms traded in Istanbul Stock Exchange.

${ }^{3}$ Majority of firms in the sampel are in manufacturing.

${ }^{4}$ www.ise.gov.tr

${ }^{5}$ For a survey on exchange rate exposure, see Muller and Verschoor (2006).

${ }^{6}$ A portfolio consisting of Euro and USD with equal weights is used in the analysis. However, using Euro only or USD only does not lead to any significant changes in the findings.

${ }^{7}$ Since price of foreign currency in terms of local currency is used, a positive $\beta_{\mathrm{s}}$ coefficient indicates a positive change in the firm value due to depreciation in the local currency.

${ }^{8}$ That is, 2000-2001 information is used to estimate the exposure $\beta$ for 2001, and information for 2000-2002 is used to estimate exposure $\beta$ for year 2002 , and so on.

${ }^{9}$ GDP value of industrialized countries is used.

${ }^{10} \mathrm{CPI}$ for industrialized countries is used to measure foreign prices.

${ }^{11}$ When exposure equals zero, firm value will not be impacted by exchange rate changes. At the same time, an exposure $\beta$ of one or negative one indicates the same exposure level. Only the change in firm value is impacted differently: in one case by an appreciation of a currency, and in other by a depreciation of the currency.

${ }^{12}$ To calculate this risk measure, same portfolio of USD and Euro is used as in Specification 1. 
Estimation results for all firms are presented in Table $1 .{ }^{13}$ The first section in the table shows the coefficient value of exchange rate exposure for the least squares (LS), fixed-effects and random-effects models. Lagrange Multiplier (LM) test indicates that GLS should be preferred over OLS. Moreover, low values of Hausman $\chi^{2}$ test statistics suggest that random-effects model, not fixed-effects model, should be used. ${ }^{14}$

Results indicate that there is a negative relationship between exchange rate exposure and real exports under Specification 1. The use of currency specific risk measure, on the other hand, does not reveal any significant relationship between risk and real exports. In addition, as indicated by the results for Specification 3, parity risk does not seem to be important for the firms in our estimation. The size of the absolute exposure $\beta$ is 0.266 , indicating that, on average, firm value is positively affected by a depreciation of local currency. However, the small size can imply that these firms are successful in hedging their exposure. In addition, given the high value of the ratio of import revenue over export revenue, which is about 0.82 , firms might be successfully matching their import expenses with export revenue. This natural hedging strategy can work if exports and imports are in the same currency, if the timing of outflows and inflows are consistent, or if parity risk is insignificant as our results show.

We also examine how this relationship is impacted by several firm-specific factors. The factors used are: the size and the age of the firms, and the dependence on export revenue. Results are provided in Table 2. We expect both larger and older firms to be impacted less by exchange rate exposure for two reasons. First, larger and older firms should face with lower firm-specific risk as they should have experience, efficient management and sufficient resources to lower their exposure (e.g. Dominguez and Tesar, 2006). Indeed, the absolute value of the average exposure is lower for larger and older firms than smaller and younger firms. However, contrary to expected, larger firms are negatively impacted by exchange rate risk, while smaller firms' exports do not respond significantly to a change in that risk, as shown by Specification 1. This result also holds when we use SD of bilateral exchange rate as the risk measure. Although parity risk seems important under random effects model, it is not significant under fixed effects model which is preferred by Hausman $\chi^{2}$ test. Given that the level of trade for a larger firm is almost 10 times more than a smaller firm, it might be possible to argue that it is the size of the exposed volume that causes this finding. For smaller firms, there does not seem to be a significant relationship.

Similarly, there appears to be a negative and significant relationship between exchange rate risk and real exports for older firms under all specifications. Moreover, parity risk also impacts trade flows negatively, indicating differences in the currency used for exports and imports. Contrary to the expected, these results imply that older firms do not have the experience or resources to eliminate that risk. Moreover, since their share of export revenue and total trade volume are lower than younger firms, it might be easier for them to shift some of their exports to the domestic market. Maturity in the market may indicate some degree of market dominance domestically as well.

Finally, we evaluate the role of the dependence on domestic and foreign markets for revenue. We expect a higher sensitivity of real exports to exchange rate exposure for firms that have a higher dependence on foreign markets for revenue. ${ }^{15}$ On the other hand, these firms should have a higher incentive to hedge that risk if relevant markets/tools exist leading to a lower exposure. In that case, we should not observe a change in exports due to a higher risk. Results indicate that exchange rate risk, under all specifications, does not impact real exports significantly. However, parity risk has a negative effect on real exports. This may indicate that these firms use different currencies for exporting and importing. In addition, low value of the ratio of import revenue over export revenue implies that these firms may not use natural hedging strategy to lower their risk.

We find that firm-specific risk has a negative effect on export volume for firms that can be characterized as domestic market oriented only when firm-specific exposure is used. This finding is not surprising as these firms receive most of their revenue from the domestic market and hence they should have more

\footnotetext{
${ }^{13}$ Given that the relative price, the income measure for importing countries, and the exchange rates do not change from firmto-firm, it is impossible to include all in one equation. Therefore, our dependent variable is regressed individually on these variables and information that is not captured by them is used as the dependent variable in the final Equation.

${ }^{14}$ The null hypothesis states no correlation, thus low values of the Hausman's $\chi^{2}$ test suggest statistical preference for a random effects model specification. It suggests that the differences between firms are not just parametric shifts of the regression function, and hence it is more appropriate to view firm specific constant terms as randomly distributed across firms.

${ }^{15}$ Of course, this will be true when hedging or shifting exports to another market, including domestic market, are not possible. This is the third country effect dicussed by Cushman (1986).
} 


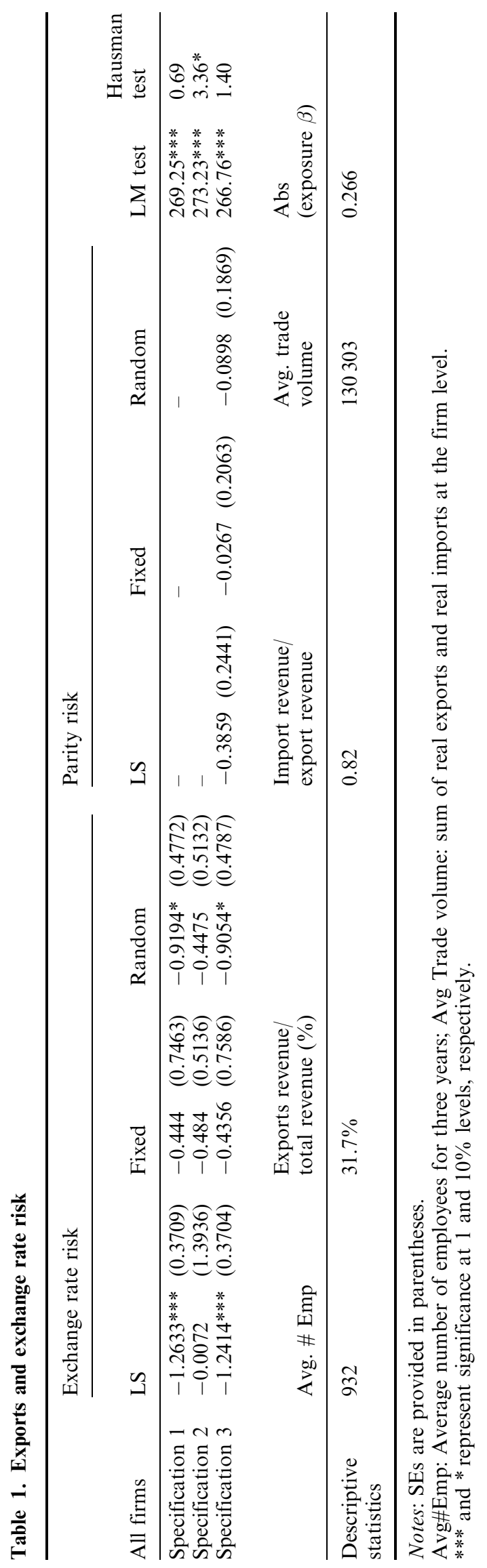




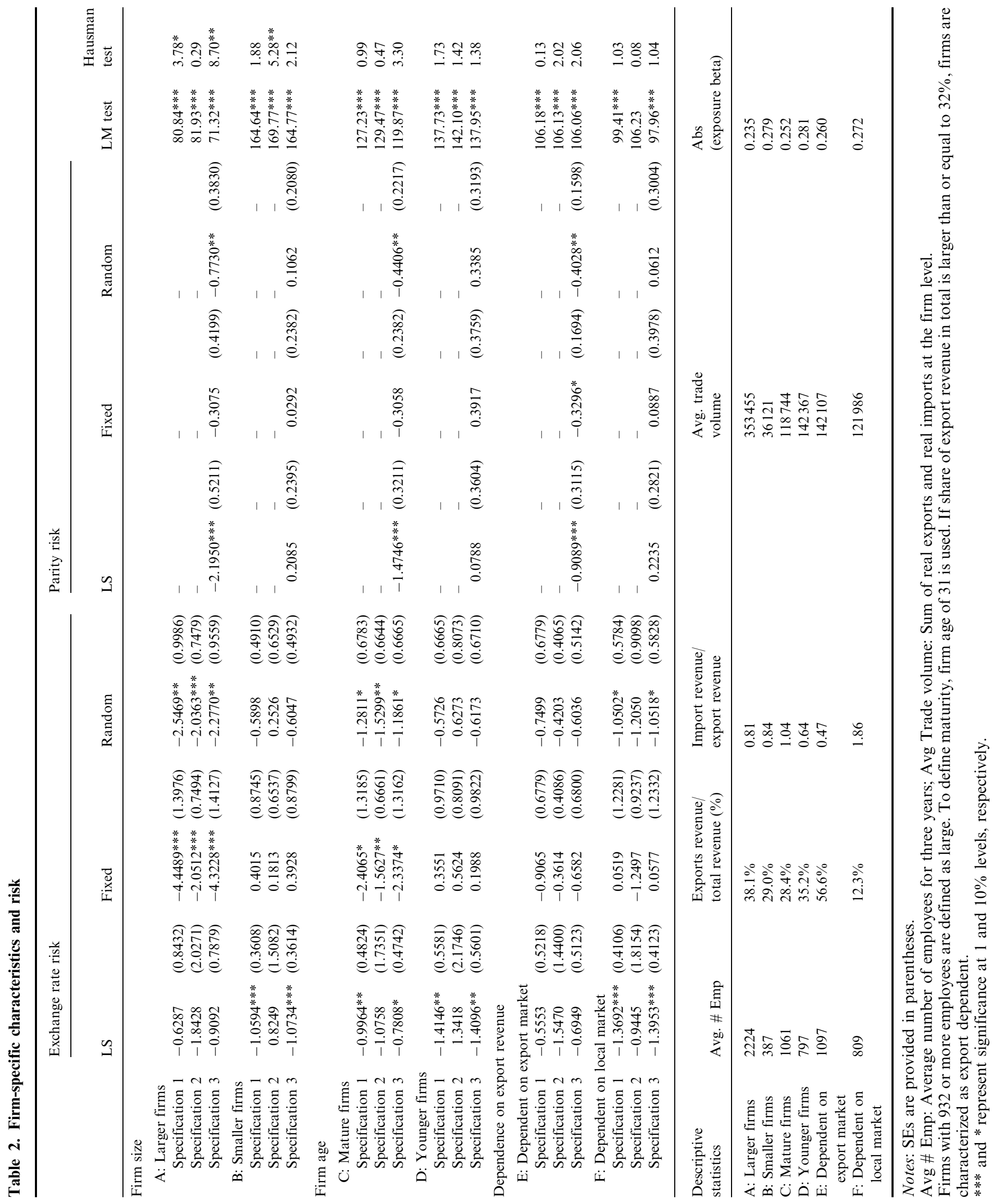


flexibility in lowering their export volume by increasing domestic sales. As it is common in the existing literature, currency level risk measure does not reveal any relationship between exports and risk.

\section{Concluding Remarks}

The relationship between exchange rate risk and real exports is investigated at the firm level utilizing three different specifications for risk. The first specification considers a firm-specific measure of risk estimated as the sensitivity firm value to exchange rate movements. A standard measure, SD of bilateral exchange rate, is also included in the analysis. The last specification incorporates parity risk, along with firm-specific risk, to evaluate the effect of differences in the currency unit for exporting and importing at the firm level. Results show that firm level real exports are negatively impacted by an increase in firm-specific exposure to exchange rate movements. There does not seem to be a significant relationship when the standard measure is used.

To evaluate the effect of the differences in firm characteristics on the risk-exports relationship, we consider firm size, firm age and the firm's dependence on export as revenue generator. Results show that larger and older firms are negatively impacted by exchange rate risk. Parity risk also affects older firms' export volume negatively. While firms that depend on export market for revenue are impacted negatively by parity risk, domestic market oriented firms' export decline significantly, due to an increase in the exchange rate risk. As discussed by Cushman (1986), it can be argued that domestic-market oriented firms can easily shift their exports to domestic markets, while export-market oriented firms cannot.

\section{Acknowledgements}

I would like to thank participants of a seminar at TOBB University, especially to Dr Ümit Özlale, for their valuable comments.

\section{References}

Adler, M. and Dumas, B. (1980) The exposure of long-term foreign currency bonds, The Journal of Financial and Quantitative Analysis, 15, 973-94.

Adler, M. and Dumas, B. (1984) Exposure to currency risk: definition and measurement, Financial Management, 13, 41-50.

Bahmani-Oskooee, M. (2002) Does black market exchange rate volatility deter the trade flows? Iranian experience, Applied Economics, 34, 2249-55.

Clark, P. B. (1973) Uncertainty, exchange risk, and the level of international trade, Western Economic Journal, 11, $302-13$.

Cushman, D. O. (1986) Has exchange risk depressed international trade? The impact of third country exchange risk, Journal of International Money and Finance, 5, 361-78.

De Grauwe, P. (1988) Exchange rate variability and the slowdown in growth of international trade, International Monetary Fund Staff Papers, 35, 63-84.

Dominguez, K. M. E. and Tesar, L. L. (2006) Exchange rate exposure, Journal of International Economics, 68, $188-218$.

Doyle, E. (2001) Exchange rate volatility and Irish-UK trade, 1979-1992, Applied Economics, 33, 249-65.

Dumas, B. (1978) The theory of the trading firm revisited, Journal of Finance, 33, 1019-29.

Ethier, W. (1973) International trade and the forward exchange market, American Economic Review, 63, 494-503.

Franke, G. (1991) Exchange rate volatility and international trading strategy, Journal of International Money and Finance, 10, 292-307.

Hassan, M. K. and Tufte, D. R. (1998) Exchange rate volatility and aggregate export growth in Bangladesh, Applied Economics, 30, 189-201.

Hooper, P. and Kohlhagen, S. W. (1978) The effect of exchange rate uncertainty on the prices and volume of international trade, Journal of International Economics, 8, 483-511.

Muller, A. and Verschoor, W. F. C. (2006) Foreign exchange risk exposure: survey and suggestions, Journal of Multinational Financial Management, 16, 385-410.

Neumann, M. (1995) Real effects of exchange rate volatility, Journal of International Money and Finance, 14, 417-26.

Pozo, S. (1992) Conditional exchange rate volatility and the volume of international trade: evidence from the early 1900s, The Review of Economics and Statistics, 74, 325-29.

Vergil, H. (2002) Exchange rate volatility in Turkey and its effect on trade flows, Journal of Economic and Social Research, 4, 83-99. 